\title{
RESTORATION PRIORITY INDEX DEVELOPMENT OF DEGRADED TROPICAL FOREST LANDSCAPE IN BATANG TORU WATERSHED, NORTH SUMATERA, INDONESIA
}

\author{
SAMSURI $^{1 *}$ I NENGAH SURATI JAYA ${ }^{2}$, CECEP KUSMANA ${ }^{3}$ \\ and KUKUH MURTILAKSONO ${ }^{4}$ \\ ${ }^{1}$ Department of Forestry, Faculty of Agriculture, Sumatera Utara University \\ Medan, Indonesia \\ ${ }^{2}$ Department of Forest Management, Faculty of Forestry, Bogor Agricultural University \\ Bogor, Indonesia \\ ${ }^{3}$ Department of Silviculture, Faculty of Forestry, Bogor Agricultural University \\ Bogor, Indonesia \\ ${ }^{4}$ Department of Watershed Management, Faculty of Agriculture, Bogor Agricultural University \\ Bogor, Indonesia
}

Received 15 April 2014/Accepted 6 September 2014

\begin{abstract}
Tropical forest fragmentation has triggered forest degradation and decreased forest connectivity. Further, degradation of tropical rain forest area reduces forest functions as global biological resources and affects livelihood of rural communities. To regain forest functions, a landscape restoration approach is needed. The research aimed to develop a restoration index model for degraded tropical forest landscapes in Batang Toru Watershed. The proposed restoration index was constructed by four indices i.e. forest degradation, forest connectivity, forest fragmentation, and socio economic indices. Regression analysis was conducted to develop models for four indices. Discriminant analysis was conducted to obtain restoration index model. The forest landscape fragmentation index increased in the period of 1989-2013, while connectivity index tended to decrease during the same period. Forest connectivity index had higher weight than other indices in calculating restoration index. This indicated that connectivity of Batang Toru forest landscape needed to be maintained and enhanced to ensure habitat quality and reduce loss of biodiversity. The research showed that Sarula Sub-watershed had high restoration index value, so it should be the first area to be restored.
\end{abstract}

Keywords: connectivity, Fragmentation, FRAGSTATS, forest ecosystem, spatial

\footnotetext{
*Corresponding author : gsamsuri@gmail.com
} 


\section{INTRODUCTION}

Recently, forest management is facing various problems arising either from natural disaster or from human activities such as forest fire, landslide, illegal logging, encroachment, shifting cultivation, and forest conversion. In some areas, the condition of degraded forest has been at a critical level; hence it might threaten the sustainability of forest ecosystem. Forest degradation has also become a global issue because it gives significant influence on global climate change. According to ITTO/IUCN (2005), the landscape of world's tropical forests remains 45\%, and fragmented spatially in degraded condition. Degradation of tropical rain forest reduces global biological resources, and causes poverty occurrence in communities in and around the degraded forest (Lamb et al. 2005).

During the period from 1970 to 1990, the degraded forest area in Indonesia was estimated to be between 0.6 - 1.2 million ha per year. The forest degradation rate in the period of 1986 -1997 was about 1.7 million ha per year (FWI/GFW 2002); between 1994 and 2000 it was about 2.83 ha million per year (MOF 2005), and in the period of 1970-1990 it was about 1.2 million per year. According to FAO (2011), forest decrease in Indonesia was at an estimated rate of $0.5 \%$ in the period of $2000-2010$ and $1.7 \%$ in the period of 1990-2000 (Fig. 1). This decrease is higher than the average of Southeastern Asia's which is at the level of $1 \%$ in the period of $1990-2000$ and $0.4 \%$ in the period of 2000-2010 (FAO 2011).

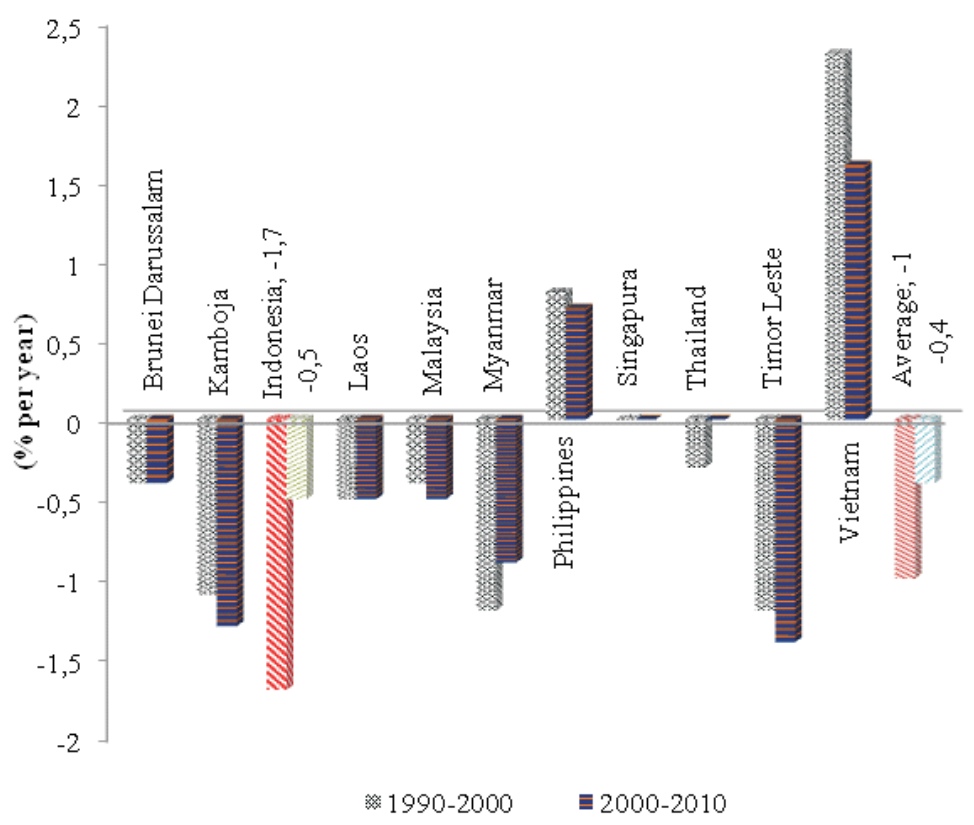

Figure 1. Deforestation rate in several South East Asia countries during 1990 - 2010 
In North Sumatera, deforestation was estimated to be $6,508,525$ ha ( $28 \%$ of total forest area) in the period of 1985-1997 (FWI/GFW 2002). Batang Toru forest as one of remaining tropical forest ecosystem in Sumatera has deforestation rate of about $1.17 \%$ per year from 1994 to 2009. The area decreased from 160,000 ha to 150,000 ha in 2009. Batang Toru gets high pressure because of the openness of access resulting from forest encroachment and forest cover change. Encroachment and forest cover change are the main drivers of forest degradation (Mendoza et al. 2005; Reddy et al. 2013). Degraded forest may cause flood, erosion and landslides (Cotler \& OrtegaLarrocea 2006).

On the other hand, Batang Toru forest landscape is habitat for 67 species of mammals, 287 species of birds, 110 types of herpetofauna and 688 types of plants. Batang Toru is the habitat of the orang-utan (Pongo abelii). The numbers of orang-utan are about $15 \%$ of total population of orang-utan in Sumatera which is estimated to be about 6,600 individuals. Besides providing important habitat for orang-utan, Batang Toru landscapes are also home for other rare animals such as Tapirus indicus, Panthera tigris sumatrae, Pardofelis marmorata, Helarctos malayanus and antelopes. Furthermore, Batang Toru forest landscape is also a habitat for unique flora of Sumatera such as Rafflesia gadutensis and several types of orchids (Perbatakusuma \& Kaprawi 2011).

The importance of the ecosystem functions of the Batang Toru as a regulator of hydrologic cycle and wildlife habitat should be maintained. Therefore, forest and land degradation should be reduced by regaining landscape condition of Batang Toru forest through the restoration of forest landscape. Forest restoration is done recently by activities to obtain a balancing function between forest conservation and rural community needed (Reitbergen-McCraken et al. 2007), regaining ecological integrity function and improving human welfare (Mansourian et al. 1986) in deforested or degraded landscapes.

Such efforts can provide optimal results if well adapted to the characteristics of the ecosystem or the type of disturbances. Recently, the Ministry of Forestry has a method to determine an index of land degradation based on biophysics condition. The ecosystem functions and socio economics aspects have not been considered as priority for area restoration. In this research, ecosystem functions and socio economics aspects are considered in determining the restoration index. To obtain the index, it needs a model design that expresses the index standard used in planning the activities of forest restoration. This research aimed to develop a restoration index model for degraded tropical forest landscapes in Batang Toru Watershed (Fig. 2a).

\section{MATERIALS AND METHODS}

This study was conducted in 3 sub-watersheds of Batang Toru Watershed i.e. Puli, Sarula, and Batang Toru Hilir Sub-watersheds. The three study areas covered three districts i.e. Tapanuli Selatan, Tapanuli Utara and Tapanuli Tengah. This study used Landsat images (Batistella et al. 2000, Apan et al. 2002) to classify land cover types in several years (1989, 2001 and 2013). Those images were landsat TM5 image of 1989, landsat ETM7 image of 2001, and landsat OLI image of 2013. This study required 


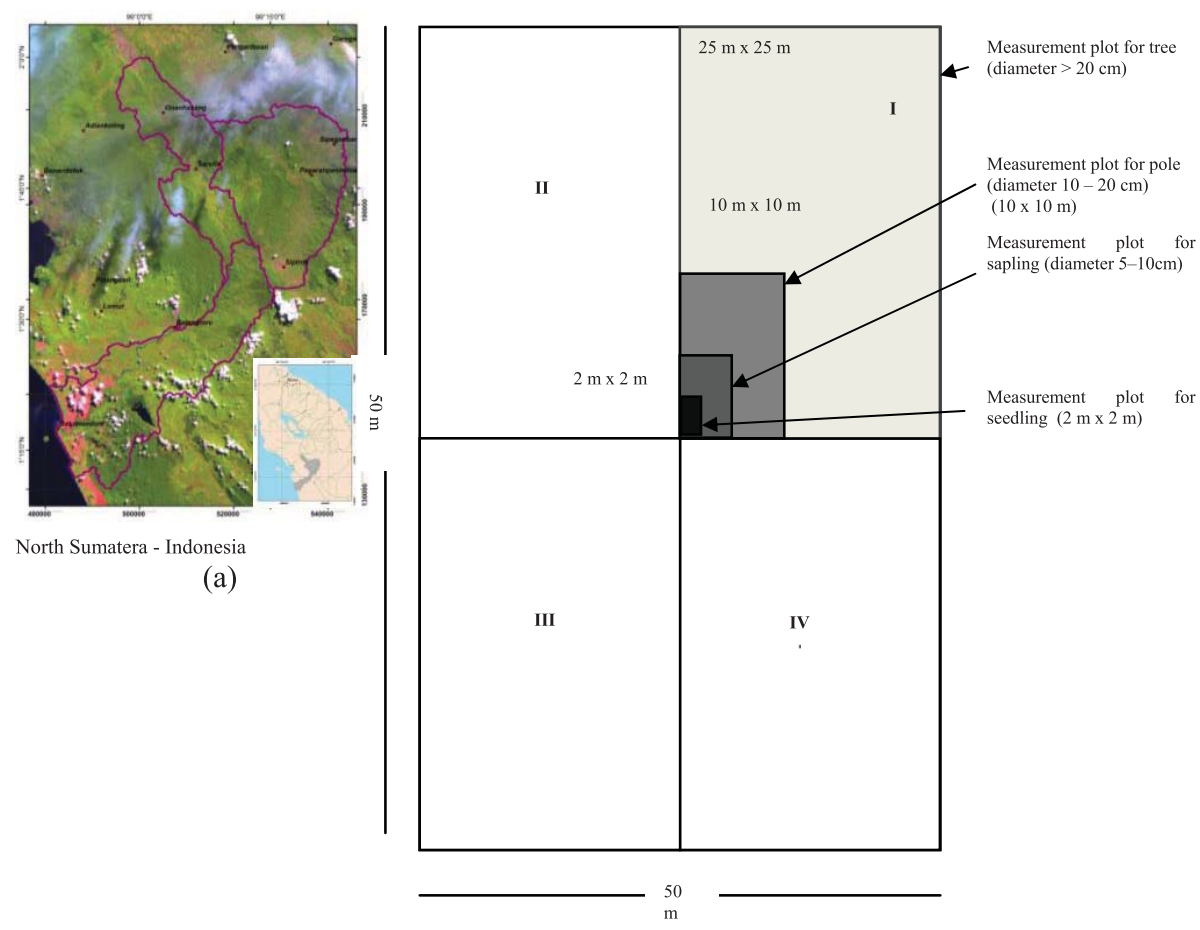

(b)

Figure 2. Location of study site (a) and design of sample plot (b)

several thematic maps including watershed, river network, road network, and contour maps. The classification of land cover types was done according to classification scheme used by the Ministry of Forestry. Field surveys were conducted to verify the land cover types and to collect vegetation data. Field sample plots were determined by purposive sampling method and laid out by representation of part of watershed (upstream, middle stream and downstream), land system and land cover types. The equipments used in the field survey were GPS, compass, Haga hypsometer, diameter tape, and questionnaires. Analysis of satellite images was conducted using ERDAS Imagine 9.1. ENVI 4.5. ArcGis 9.x was used in the spatial analysis of thematic maps (contour, road, and river maps). FRAGSTATS ver 3.3 (McGarigal \& Marks 1995; McGarigal et al. 2002) was used to derive necessary landscape metrics.

The research consisted of 5 stages to get the restoration index, as follows:

\section{Forest Degradation Index}

Landsat images were interpreted to get the Normalized Difference Vegetation Index (NDVI) and land cover types for year of 1989, 2000 and 2013 (Jaya 2009). A field check was conducted to verify the classified land cover types. In addition, vegetation data were collected in several square sample plots of $2,500 \mathrm{~m}^{2}$ (Fig. 2b). 
Trees in different growth stages were measured in four different size quadrants namely quadrant 1, 2, 3 and 4. An analysis of the vegetation data was conducted to get the degree of forest degradation (Kreb 1989, Magurran 1988). Forest degradation was approached using NDVI value class. NDVI was predicted using vegetation parameters namely species diversity index $\left(\mathrm{x}_{1}\right)$, basal area $\left(\mathrm{x}_{2}\right)$, and stand density $\left(\mathrm{x}_{3}\right)$. Each range of NDVI was scored using Likert scale (Syarifi et al. 2007) (Table 1), then it was used to model forest degradation index through regression analysis (Puspaningsih 2011, Rohyani 2012). The independent variables were distance to main road $\left(\mathrm{x}_{4}\right)$, distance to main river $\left(\mathrm{x}_{5}\right)$ and percent of slope $\left(\mathrm{x}_{6}\right)$.

\section{Forest Landscape Fragmentation (FLF) Index}

Forest land cover types were analyzed using the FRAGSTATS software. FRAGSTATS analysis was performed to derive landscape metrics. The range length of orang-utan was used as data input in FRAGSTATS analysis. FLF degree was calculated based on landscape metrics (McGarigal \& Marks 1995). Landscape metrics used to determine the degree of FLF were patch number per area (patch density), proximity and contiguity (Fahrig 2003, McGarigal et al. 2002). Each landscape metric was classified (Table 1) and scored using Likert scale (Syarifi 2007) indicating the degree of FLF. Hence, it was used to develop FLF index by regression analysis (Puspaningsih 2011, Rohyani 2012). The independent variables were value of contiguity between patch $\left(\mathrm{x}_{7}\right)$, proximity value of each patch $\left(\mathrm{x}_{8}\right)$, and the number of patch $\left(\mathrm{x}_{9}\right)$

Table 1 Score of each sub factors

\begin{tabular}{|c|c|c|c|c|c|c|c|}
\hline No & $\begin{array}{l}\text { Sub } \\
\text { factor }\end{array}$ & Value & Score & No & Sub factor & Value & Score \\
\hline \multirow{5}{*}{1} & & $<0$ & 5 & \multirow{5}{*}{5} & \multirow{5}{*}{ Connectan } & $<20$ & 1 \\
\hline & & $0-0.25$ & 4 & & & $20-40$ & 2 \\
\hline & NDVI & $0.25-0.50$ & 3 & & & $40-60$ & 3 \\
\hline & & $0.50-0.75$ & 2 & & & $60-80$ & 4 \\
\hline & & $>0.70$ & 1 & & & $>80$ & 5 \\
\hline \multirow{5}{*}{2} & Number & $>325$ & 5 & \multirow{5}{*}{6} & \multirow{5}{*}{$\begin{array}{l}\text { Radius of } \\
\text { gyration }\end{array}$} & $<200$ & 1 \\
\hline & of patch & 285-325 & 4 & & & $200-400$ & 2 \\
\hline & per area & 245- 285 & 3 & & & $400-600$ & 3 \\
\hline & (patch & $205-245$ & 2 & & & $600-800$ & 4 \\
\hline & density) & $<205$ & 1 & & & $>800$ & 5 \\
\hline \multirow{5}{*}{3} & \multirow{5}{*}{ Proximity } & $>3.270$ & 5 & \multirow{5}{*}{7} & \multirow{5}{*}{ Employment } & Farmer & 5 \\
\hline & & $2.551-3.270$ & 4 & & & Labour/official & \\
\hline & & $1.234-2.551$ & 3 & & & employee & 3 \\
\hline & & $555-1.233$ & 2 & & & & \\
\hline & & $<554$ & 1 & & & Un-employee & 1 \\
\hline \multirow{5}{*}{4} & \multirow{5}{*}{ Contiguity } & $<0.2$ & 5 & & \multirow{5}{*}{$\begin{array}{l}\text { Salary/income } \\
\text { (Million } \\
\text { IDR/month) }\end{array}$} & $<0.6$ & 5 \\
\hline & & $0.2-0.4$ & 4 & & & $6-3$ & 4 \\
\hline & & $0.4-0.6$ & 3 & 8 & & $\begin{array}{l}3-6 \\
6-8\end{array}$ & 3 \\
\hline & & $0.6-0.8$ & 2 & & & $\begin{array}{l}0-8 \\
>8\end{array}$ & 2 \\
\hline & & $>0.8$ & 1 & & & & 1 \\
\hline
\end{tabular}




\section{Forest Landscape Connectivity (FLC) Index}

FLC degree was calculated based on landscape metrics indicating connectivity i.e. radius of gyration and connectan of forest area (Fahrig 2003; McGarigal et al. 2002). Each metric was scored (Table 1) to determine degree of FLC, then it was used to model FLC index by regression analysis (Puspaningsih 2011; Rohyani 2012). The independent variables were value of connectan among forest patch $\left(\mathrm{x}_{10}\right)$ and value of radius of gyration of each forest patch $\left(\mathrm{x}_{11}\right)$.

\section{Socio Economics Index}

Socio economics perception of people living surrounding forest area was studied by interviewing them. Interview was guided by semi-structured method using questionnaires. Each answer was scored using Likert scale (Syarifi 2007) (Table 1). Regression analysis was used to model socio economics index (Puspaningsih 2011; Rohyani 2012). The independent variables were maximum score of income in millions rupiahs earned by people's group around the forest $\left(\mathrm{x}_{12}\right)$, and score of occupation type group namely farmer group; company labor, government officer and informal sector labor group, and plantation estate owners group $\left(\mathrm{x}_{13}\right)$.

\section{Developing Restoration Index}

Four map indices were overlaid and samples were taken from 225 unit (4 ha per unit). Then, restoration index $(z)$ was developed using four indices i.e. forest degradation index $\left(\mathrm{y}_{1}\right)$, forest landscape fragmentation index $\left(\mathrm{y}_{2}\right)$, forest landscape connectivity index $\left(\mathrm{y}_{3}\right)$ and socio economics index $\left(\mathrm{y}_{4}\right)$. Discriminant analysis was perfomed to get a restoration index model (Thatam et al. 1998; Sifriyani 2012).

\section{RESULTS AND DISCUSSION}

\section{Forest Degradation Index}

Regression analysis resulted in this study showed that the model of forest degradation was $\mathrm{y}=1+2.0771 \mathrm{x}_{1}+0.0094 \mathrm{x}_{2}-1.4675 \mathrm{x}_{3}$ with determination coefficient of $90 \%$. Therefore, spatial and statistical analyses were also conducted and resulted the model of forest degradation index as $\mathrm{y}_{1}=1.10571-0.00005 \mathrm{x}_{4}-0.00006 \mathrm{x}_{5}$ $0.00732 \mathrm{x}_{6}$ with determination coefficient of $63.19 \%$. Based on the model of forest degradation index, it was found out that higher stand density value and higher basal area proved that the forest condition were less degraded. Vegetation density in three sub-watersheds was low and the estimates from different plots ranged from 12 to 93 individuals per ha, other Sumateran lowland mountain natural forest could reach 120 tree per ha (Whitten et al. 1987). The current stand density value indicated that forest cover decreased and it indicated degradation (Lund 2009).

Morever, the nearness to road and river networks trigerred forest degradation because the road and river become people's access to go inside and outside the forest. Generally, river and road networks are used to enter the forest. Closer distance from river and road networks to the forest means the forest has more pressure than other forest locations. The road and river can be used to estimate forest degradation risk. 
Forest in the study area was located on relatively high elevation and rough topography. In this condition, slope could cause difficulties in accessing and disturbing forest. Human tends to choose land having easier accessibility to settle down, which leads to land conversion.

The model of forest degradation was used to derive forest degradation map (Fig. 3). Forest degradation map divided forest landscape into degradation classes: lower, low, moderate, and high. Degradation of forest landscape was located in area close to road and river networks. Therefore, forest landscape close to the road should receive higher priority to be restored.

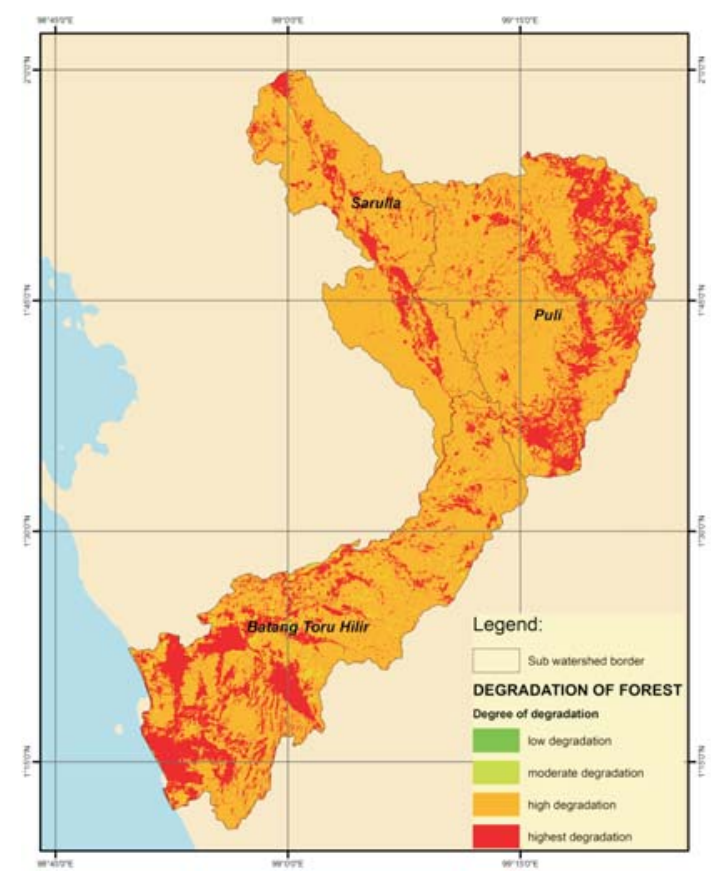

Figure 3. Forest degradation index of Batang Toru Watershed

\section{Forest Landscape Fragmentation (FLF) Index}

Orang-utan is endemic fauna in the forest region of Batang Toru needing proper habitat in Batang Toru's forest. One main goal of Batang Toru landscape restoration was to provide habitat for orang-utan and other biodiversity. The orang-utan habitat characteristics were used as input data in landscape metrics analysis. The day range length of orang-utan was at least $500 \mathrm{~m}$ per day. This radius was used as basic calculation for landscape metrics on every $500 \mathrm{~m}$. This radius area was assumed as minimum habitat of orang-utan. Furthermore, the day range length of orang-utan was not more than $1,000 \mathrm{~m}$ per day. This radius was used as an input for forest edge length of metrics landscape (Sinaga 1992). 
Regression model of FLF index resulted from this study was $\mathrm{y}_{2}=0.7819-0.576 \mathrm{x}_{7^{-}}$ $0.0000001 \mathrm{x}_{8}+0.0552 \mathrm{x}_{9}$, with determination coefficient of $87.20 \%$. Based on landscape metrics value, it was known that FLF degree increased from 1989 to 2013 which was indicated by the increasing of patch density (Forman \& Godron 1986; Forman 1995; Fahrig 2003) per ha (Fig. 4a) and by the increasing of patch proximity (Fig. 4b). Patch density in three sub-watersheds (Puli, Sarula and Batang Toru Hilir) rose from about 0.10 in 1989 to 0.60 in 2013. The area of low FLF index to medium FLF index was bigger than that of high FLF index. Most FLF index area was in the road distance of $1,000 \mathrm{~m}$ to 5,000 $\mathrm{m}$ where people could reach out and entered the forest in a day (Jaya et al. 2007). FLF index map showed that most forest landscape in Batang Toru Watershed was in low FLF index $(<0.2)$, so it was categorized as low FLF category (Fig. 5a). Low FLF supported ecosystem function restoration because the material flow in the ecosystem still ran quite well due to low isolated forest patch which would not reduce organism mobility inside the forest.

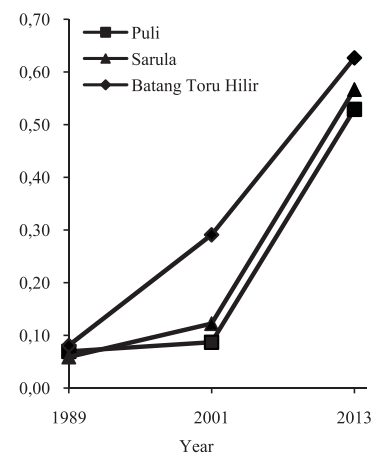

(a)

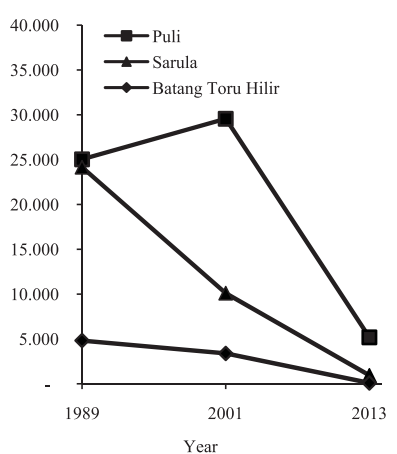

(b)

Figure 4. Forest patch density (a) and forest patch proximity (b)

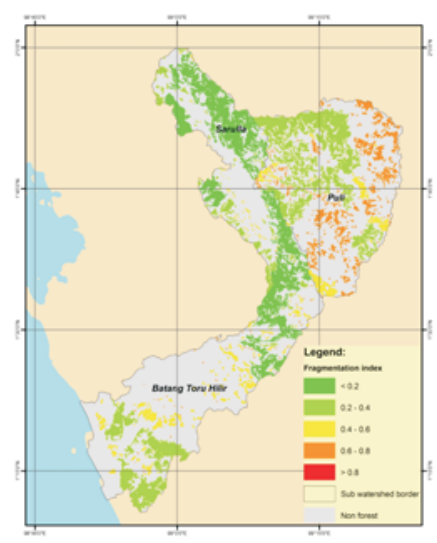

(a)

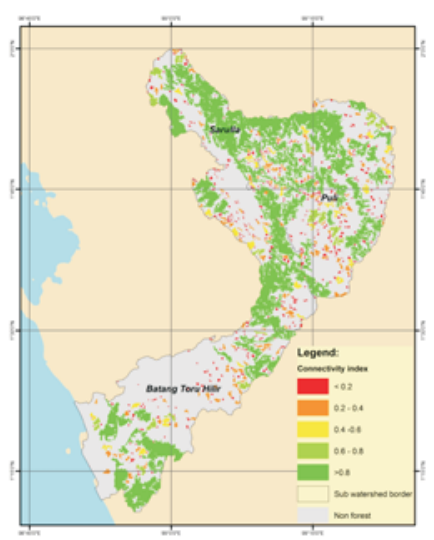

(b)

Figure 5. Forest fragmentation (a) and forest connectivity (b) of year 2013 in Batang Toru Watershed 


\section{Forest Landscape Connectivity (FLC) Index}

Forest Landscape Connectivity (FLC) index in Batang Toru Watershed decreased from 1989 to 2013. It was indicated by the decreasing of radius of gyration (Fahrig 2003) from 400-700 range in 1989 to 50-200 range in 2013 (Fig. 6a) and by the decreasing of connectan value from 3-9\% range in 1989 to 0-2\% range in 2013 (Fig. $6 \mathrm{~b})$. Regression analysis resulted from this study showed that the model for FLC index was $\mathrm{y}_{3}=0.1144+0.0006 \mathrm{x}_{10}+0.1954 \mathrm{x}_{11}$ with determination coefficient of $66.16 \%$. Most area of Puli Sub-watershed had medium connectivity index, while high connectivity index belonged to forest path in Sarula Sub-watershed. A small forest patch which was located in Batang Toru Hilir Sub-watershed had very low connectivity index because it was separated by other land cover types. Non-forest cover area was located between small forest patches. Larger non-forest cover area made small forest patches more separated from others. This will be a barrier for organism movement between forest patches.

The derived map of FLC index (Fig. 5b) showed that Puli Sub-watershed had the highest FLC index compared to Sarula and Batang Toru Hilir Sub-watersheds. Meanwhile, Batang Toru Hilir and Sarula Sub-watersheds had low FLC index. Batang Toru Hilir Sub-watershed was located in downstream of Batang Toru Watershed where many lands clearing activities occurred, caused by long distance between forest patch remained. This condition was also occurred in Puli Sub-watershed located in upper stream of Batang Toru Watershed.

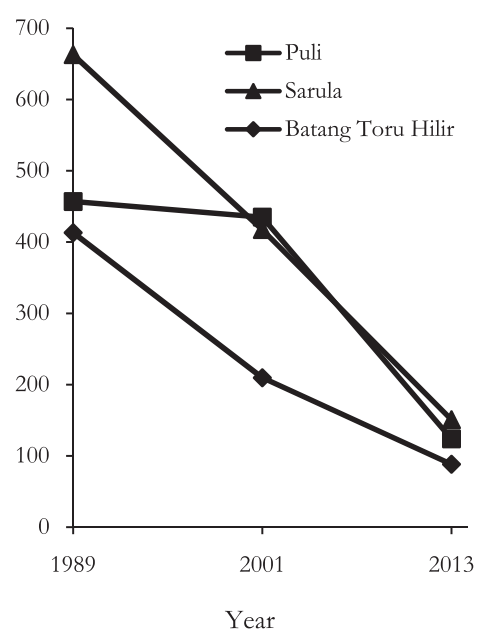

(a)

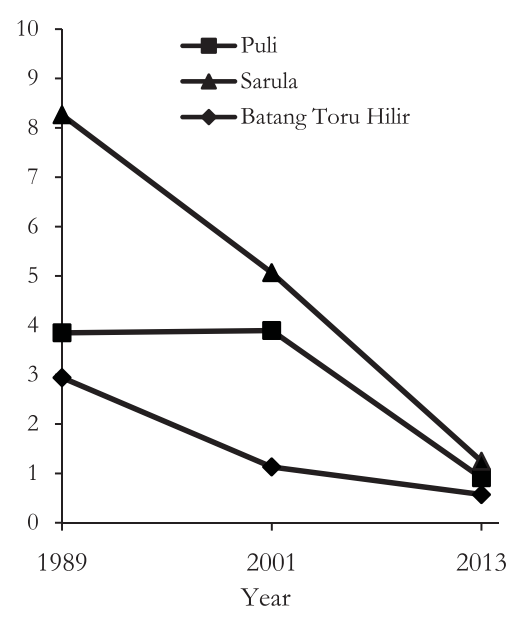

(b)

Figure 6. Radius of gyration (a) and forest patch connectan (b) of each sub-watershed 
FLC map also showed that the most forest landscape of Sarula Sub-watershed had high connectivity index (0.5-0.6). The forest landscape with higher connectivity index was forest of Sarula (0.6-0.8) located along main road through the sub-watershed. By restoring this forest, the forest landscape would be connected with the closest forest patches, so the connectivity between forest patches would be high and would improve the functional relationship (Fry \& Tress 2007) in forest ecosystem.

Loss of natural connectivity of ecosystem is threat in distribution and survival of orang- utan and other wildlife. As the habitat of wildlife, the FLC of Batang Toru is important for diversity conservation. More serious attention is needed to improve the connectivity of forest landscape and habitat conservation, because landscape connectivity facilitates organism movement, genetical exchange, and other ecology of material flow (Crooks \& Sanjayan 2006). Habitat requirements for fauna and flora is the main key in biodiversity conservation, including stability and integrity of natural ecosystem (Taylor et al. 1993; Collinge 2000). Therefore, it is very important to consider connectivity as a base in planning conservation and landscape change analysis.

\section{Socio Economics Index}

The model of socio economics index resulted from this study was $\mathrm{y}_{4}=0.6545$ $0.043077 \mathrm{x}_{12}+0.004396 \mathrm{x}_{13}$ with determination coefficient of $24.78 \%$. Socio economics condition became a main key for the success of landscape restoration activities. People's perceptions on forest landscape restoration activities were different. The perceptions depended on people's level of income, education, main occupation types, age and duration of staying. The analysis showed that occupation types and level of income significantly affected people's participation possibility in forest landscape restoration.

Based on occupation types, employed people were highly depended on natural resources quality and therefore, they absolutely agreed and would participate in all restoration steps. Farmer group was more supportive in landscape restoration compared to plantation workers or owners. The farmer group would participate in landscape restoration to have more income and land for cultivation. As well as farmers, low income people tended to participate in restoration activities to have more income (Fig. $7 \mathrm{a})$.

People owning large estate area tended not to participate in landscape restoration. Those people were worried their plantation would be disturbed, so it might reduce production of the plantation. People with high level of income disagreed and would not participate in forest landscape restoration. This condition should become consideration in determining location and determining partners in managing forest landscape restoration. Forest landscape restoration programs should increase people's welfare and produce more woods from forest plantation (Nawir et al. 2008).

\section{Restoration Index}

This study showed that the restoration index model was $z=0.133 \mathrm{y}_{1}+0.024 \mathrm{y}_{2}+$ $0.939 \mathrm{y}_{3}+0.079 \mathrm{y}_{4}$ with correlation coefficient of $55.7 \%$. Based on value of cannonical 
discriminant coefficient, it was found out that socio economic index had less impact compared to the other four predictors, while the most influential model was connectivity index model. Hit ratio value from discriminant analysis is $54.5 \%$, which was sufficient for grouping into 3 different classes. Based on Press' $s$ Q test using alpha value of 0.05 , the discriminant function result was accurate, because Press's $Q$ value was bigger than $X^{2}$ table value. Hence, the restoration index model was used to create restoration index map (Fig. $7 \mathrm{~b}$ ). The figure shows that high restoration index was located in Sarula Sub-watershed. It meant that when the restoration project was to be conducted, Sarula Sub-watershed should be the first area to be restored.

Based on matrix value of discriminant function, it was found out that the connectivity index had canonical coefficient value higher than other indices (Selman 2006), therefore, it became the most important index followed by forest degradation index. Connectivity index is important in some research because it is potential in mitigating habitat fragmentation impact (Anderson \& Jenkins 2006). Considering the landscape connectivity index would ensure the connectivity of wildlife habitat. Socio economic index had less influence in the model indicating that people's participation possibility was relatively less important as consideration in restoration activity planning when the forest landscape was highly degraded. People's participation possibility should be encouraged to increase support in forest landscape restoration plan.

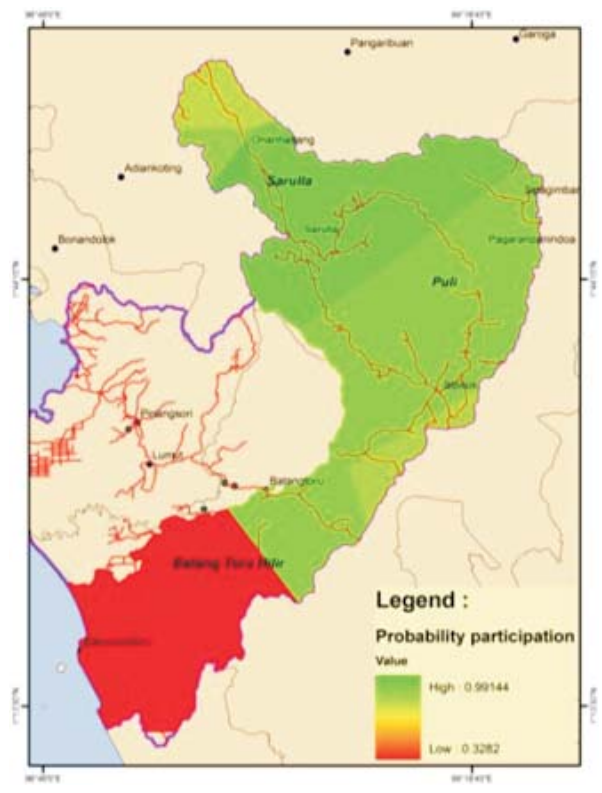

(a)

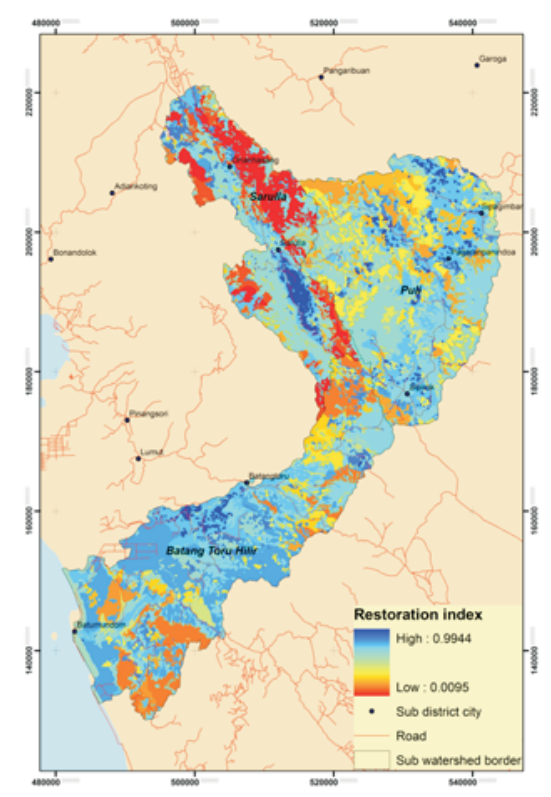

(b)

Figure 7. Possibility participation map (a) and restoration index priority of forest landscape Batang Toru Watershed (b) 
Increasing of ecosystem connectivity is one main objective of forest landscape management (Saura et al. 2011), and also maintenance of stability and integrity of natural ecosystem (Decout et al. 2010). Forest landscape restoration is aimed to restore forest landscape as close as natural ecosystem. Forest patch connectivity and forest degradation level become the most important indices, therefore, consideration to improve connectivity between separated patches and degradation levels becomes high priority. These indices will improve the current guidelines and methods for forest restoration. Biophysical factor is the main consideration in planning site restoration (MoF and JICA, 2014). Recently, land and forest biophysical characteristics are also used to determine site priority for land rehabilitation. Ecologically, the connectivity index is one important factor in material flow and material cycle in forest ecosystem. In Sarula Sub-watershed, most forest degradation was in very high restoration index area. The index showed that Sarula Sub-watershed became the main priority for landscape restoration activities in Batang Toru Watershed. Restoring landscape of Sarula Sub-watershed will improve the whole condition of Batang Toru Watershed because Sarula Sub-watershed is located in the upstream of Batang Toru Watershed.

\section{CONCLUSIONS}

Batang Toru forest landscape was heading for heavy degradation indicated by decreasing of species diversity level, increasing of medium and high ecosystem pressures, increasing of forest landscape fragmentation, declining of forest landscape connectivity.

Forest landscape restoration index was determined by forest landscsape connectivity index and forest degradation index. The forest connectivity index should be considered in planning site restoration to ensure wildlife habitat quality and biodiversity. The restoration index would enhance the current guidelines and methods for forest restoration. Forest fragmentation was potential indicator to determine priority for site restoration.

People's participation possibility gave less influence in landscape restoration index model. People needed to be encouraged to increase their involvement in forest landscape restoration activities in Batang Toru Watershed. The map of forest landscape restoration index shows that Sarula Sub-watershed to be the first area restored before other sub watersheds. The restoration index needs other factors to fulfill all requirements such as land degradation index. Therefore, further research is needed to design site restoration site in priority sub-watershed area.

\section{ACKNOWLEDGEMENTS}

This research was part of $\mathrm{PhD}$ thesis of the first author, funded by SEAMEOBIOTROP DIPA 2013. The authors extended deep appreciation to the Ministry of Education and Culture, Republic of Indonesia for the scholarship and support to 
accomplish this paper. Sincere appreciation was also extended to anonymous reviewers for corrections and comments.

\section{REFERENCES}

Anderson B, Jenkins CN. 2006. Applying Nature's Design: Corridors as a Strategy for Biodiversity Conservation. New York, (US): Columbia University Press.

Apan AA, Steven SR, Mark SP. 2002. Mapping and analysis of changes in the riparian landscape structure of the Lockyer Valley catchment, Queensland, Australia. Landscape Urban Planning 59 (1):43-57.

Batistella M, Eduardo S, Brondizio, Emilio F, Moran. 2000. Comparative analysis of landscape fragmentation in Rondônia, Brazilian Amazon. International Archives of Photogrammetry and Remote Sensing 33: 148 55

Collinge SK. 2000. Effects of grassland fragmentation on insect species loss, colonization, and movement patterns. Ecology 81(8):2211-26.

Cotler H, Ortega-Larrocea MP. 2006. Effects of land use on soil erosion in a tropical dry forest ecosystem, Chamela watershed, Mexico. Catena 65:107-17.

Crooks KR, Sanjayan M. 2006. Connectivity Conservation. New York, US: Cambridge University Press.

Decout S, Manel S, Miaud C, Luque S. 2010. Connectivity and landscape patterns in human dominated landscape: a case study with the common frog Rana temporaria. [http://symposcience.org]

Fahrig L. 2003. Effect of habitat fragmentation on biodiversity. Annu Revi Ecol, Evol, Syst 34(1):487-515.

Food and Agriculture Organization. 2011. State of world's forest 2011. Rome.

Forest Watch Indonesia/Global Forest Watch. 2002. The state of the forest Indonesia. Bogor; 2002.

Forman RTT, Godron M. 1986.Landscape Ecol.New York (US): Wiley.

Forman RTT. 1195. Land Mosaics: The Ecology of Landscapes and Regions, 2 Edition. Cambridge (UK): Cambridge University Press; 1995.

Fry G, Tress B. 2007. Integrative landscape research: facts and challenges. In Key Topics in Landscape Ecology. Edited by Wu J, Hobbs R. Cambridge (UK): Cambridge University Press; p. 246-68.

International Timber Trade Organization/International Union Conservation Nature. 2005. Restoring forest landscapes. An introduction to the art and science of forest landscape restoration. ITTO Technical Series 23. Yokohama.

Jaya INS, Boer R, Samsuri. 2007. Developing fire risk index in Central Kalimantan. International Research Institute and Bogor Agricultural University [research report]. Bogor (ID): Institut Pertanian Bogor.

Jaya INS. 2009. Analysis Citra Digital: Perspektif Penginderaan Jauh untuk Pengelolaan Sumber Daya Alam. Bogor (ID): Institut Pertanian Bogor.

Kreb CJ. 1989.Ecological Methology. Columbia (US): Harper Collins Publisher.

Lamb D, Erskine PD, Parrota JA. 2005. Restoration of degraded tropical forest landscapes. Science 310(5754):1628-32.

Lund HG. 2009. What is a degraded forest. forest information services. [http://home.comcast.net/ gyde/ 2009 forestdegrade.doc].

Magurran AE. 1988. Ecological Diversity and Its Measurement. Yogyakarta (ID): Cambridge University Press.

Mansourian S, Vallauri D, Dudley N (eds.). 1986. Forest restoration in landscapes : beyond planting trees. Springeronline.com.

McGarigal K, Cushman SA, Neel MC, Ene E. 2002. FRAGSTATS: spatial pattern analysis program for categorical maps. [http://www.umass.edu/landeco/research/fragstats/fragstats.html]. 
BIOTROPIA Vol. 21 No. 2, 2014

McGarigal K, Marks BJ. 1995. FRAGSTATS: spatial pattern analysis program for quantifying landscape structure. Gen Tech Rep PNW-GTR-351

Mendoza E, Fay J, Dirzo R. 2005. A quantitative analysis of forest fragmentation in Los Tuxtlas, Southeast Mexico: patterns and implications for conservation. Revista Chilena De Historia Natura 78: 451-67.

Ministry of Forestry. 2005. Statistik Kehutanan Indonesia. Jakarta.

Ministry of Forestry (MoF) and Japan International Cooperation Agency (JICA). 2014. Pedoman dan tata cara restorasi di kawasan konservasi (Hutan Hujan Tropis Pegunungan dan Hutan Mooson Tropis. Jakarta (ID).

Nawir A, Murniati, Rumboko L (eds). 2008. Rehabilitasi hutan di Indonesia, akan kemanakah arahnya setelah lebih dari tiga dasawarsa?. Bogor (ID): Center for International Forestry Research (CIFOR).

Perbatakusuma EA, Kaprawi F. 2011. Kajian Spasial Laban Kritis Berbasis Sistim Informasi Geografis untuk Rehabilitasi Kawasan Koridor Satwa Liar dan Harangan Desa di Kawasan Hutan Batang Toru Provinsi Sumatera Utara. Medan (ID): Konsorsium Ikon Koridor to Sigadis.

Puspaningsih N. 2011. Pemodelan spasial dalam monitoring reforestasi Kawasan Pertambangan Nikel PT. Inco di Sorowako Sulawesi Selatan. PhD thesis. Bogor (ID): Institut Pertanian Bogor.

Reddy CS, Sreeleksmi S, Jha CS, Dahdwal VK. 2013. National assesment of forest fragmentation in India: landscape indices as measure of the effect of fragmentation and forest cover change. Ecol Eng 60 : $453-64$.

Rietbergen-McCracken J, Maginnis S, Sarre A (eds). 2007. The Forest Landscape Restoration Handbook (Earthscan Forestry Library). London (UK): James and James.

Rohyani IS. 2012. Pemodelan spasial kelimpahan collembola tanah pada area revegetasi tambang PT Newmont Nusa Tenggara. PhD thesis. Bogor (ID): Institut Pertanian Bogor.

Saura S, Vogt P, Velázquezc J, Hernandoa A, Tejeraa R. 2011. Key structural forest connectors can be identified by combining landscape spatial pattern and network analyses. Forest Ecol Manag 262: 150-60.

Selman P. 2006. Planning at The Landscape Scale. New York (US): Routledge.

Sinaga T. 1992. Studi habitat perilaku orang utan (Pongo pygmaeus) di Bahorok Taman Nasional Gunung Leuser. Master thesis. Bogor(ID): Institut Pertanian Bogor.

Sifriyani. 2012. Comparison discriminant analysis and analysis neural network for classifying data. Jurnal Eksponensial 3 (2): 55-61.

Syarifi MA, Herwijnen M, van Toorn WH van deen. 2007. Spatial Decision Support System. Ensdhede (NL): International Institut for Aerospace Survey and Earth Science (ITC).

Tatham RL, Hair JF, Anderson RE and Black WC. 1998. Multivariate Data Analysis. New Jersey (US): Prentice Hall.

Taylor PD, Fahrig L, Henein K, Merriam G. 1993. Connectivity is a vital element of landscape structure. Oikos 68: 571-3

Whitten, Anthony J. Damanik, Sengli J, Anwar, Jazanul, Hisyam, Nazaruddin. 1987. The Ecology of Sumatera. Yogyakarta (ID): Gadjah Mada University Press. 